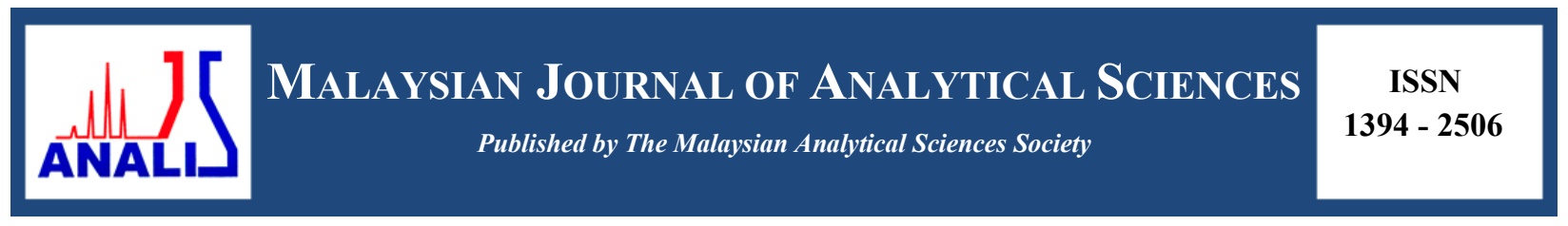

\title{
PRELIMINARY STUDY ON PRODUCTION OF MONOACYLGLYCEROL AND DIACYLGLYCEROL OF VIRGIN COCONUT OIL VIA ENZYMATIC GLYCEROLYSIS USING LIPASE Candida antarctica (Novozyme 435)
}

\author{
(Kajian Awal Penghasilan Monoasilgliserol dan Diasilgliserol Minyak Kelapa Dara Melalui \\ Gliserolisis Berenzim Menggunakan Lipase Candida antarctica (Novozyme 435)) \\ Darfizzi Derawi ${ }^{1 *}$, Nurin Afiqah Zairul Azman ${ }^{1}$, Mohd Fadlly Jumadi ${ }^{2}$ \\ ${ }^{1}$ School of Chemical Sciences and Food Technology, Faculty of Science and Technology, \\ Universiti Kebangsaan Malaysia, 43600 UKM Bangi, Selangor, Malaysia \\ ${ }^{2}$ Sime Darby Research Sdn. Bhd., 42690 Carey Island, Selangor, Malaysia \\ *Corresponding author: darfizzi@ukm.edu.my
}

Received: 29 January 2016; Accepted: 22 November 2016

\begin{abstract}
Virgin coconut oil (VCO) consists mainly of saturated medium chain fatty acids which are 48.8\% lauric acid (C12:0) and $20.0 \%$ myristic acid (C14:0). Both medium chain fatty acids are essential in increasing metabolism and possess antibacterial properties. These fatty acids of VCO are in the form of triacylglycerols (TAGs). Hence, VCO has to be converted into a simpler form such as mono- and diacylglycerols (MAGs and DAGs) in order to increase its antibacterial functionality in metabolism. In this paper, VCO was chemically modified via enzymatic glycerolysis reaction conducted at a molar ratio of 1:1 (VCO:glycerol) and catalysed by lipase enzyme, Candida antarctica (Novozyme 435). The reaction was carried out in an incubator shaker at $50{ }^{\circ} \mathrm{C}$ and $250 \mathrm{rpm}$ of reaction speed. Reaction parameters were reaction time (24 and 48 hours) and enzyme concentrations (3, 5 and $10 \%$ ). The product comprises of 3.3\% MAG, 3.6\% DAG and 93.1\% TAG has been obtained by preliminary optimum reaction condition at temperature of $50{ }^{\circ} \mathrm{C}$ with $5 \%$ wt of enzyme concentration at 24 hours of reaction time. Chemical analysis techniques used were thin layer chromatography (TLC), fourier transformation infrared (FT-IR) spectroscopy and gas chromatography (GC). Products are potentially to be used as food emulsifier, pharmaceutical binders, antibacterial products as well as food additives.
\end{abstract}

Keywords: virgin coconut oil, glycerolysis, lipase enzyme, monoacylglycerol, diacylglycerol

\section{Abstrak}

Kandungan utama minyak kelapa dara (VCO) adalah asid lemak tepu berantai sederhana dengan $48.8 \%$ adalah asid laurik (C12:0) dan 20.0\% asid miristik (C14:0). Asid lemak dengan rantaian sederhana adalah penting dalam meingkatkan kadar metabolisma dan mempunyai ciri-ciri anti-bakteria. Asid lemak dalam VCO adalah dalam bentuk triasilgliserol (TAG). Oleh itu, VCO perlu ditukarkan kepada bentuk yang lebih ringkas seperti mono dan diasilgliserol (MAG dan DAG) untuk meningkatkan fungsi anti-bakteria dalam metabolisma. Dalam kajian ini, VCO diubahsuai secara kimia melalui tindak balas gliserolisis berenzim yang dijalankan pada nisbah molar 1:1 (VCO:gliserol) dengan enzim lipase Candida antarctica (Novozyme 435) sebagai pemangkin. Tindak balas ini telah dijalankan dalam inkubator bergetar pada suhu $50{ }^{\circ} \mathrm{C}$ dengan kelajuan $250 \mathrm{rpm}$. Parameter tindak balas yang dilakukan adalah masa tindak balas (24 dan 48 jam) dan kepekatan enzim (3, 5 dan 10\%). Hasil tindak balas terdiri daripada 3.3\% MAG, 3.6\% DAG dan 93.1\% TAG telah diperolehi dengan kondisi tindak balas optimum awal pada suhu tindak balas $50{ }^{\circ} \mathrm{C}$ dengan kepekatan enzim $5 \%$ wt pada 24 jam tindak balas. Teknik analisis kimia yang digunakan adalah kromatografi lapisan nipis (TLC), spektroskopi transformasi fourier inframerah (FT-IR) dan kromatografi gas (GC). Produk berpotensi untuk digunakan sebagai pengemulsi makanan, pengikat dalam farmaseutikal, produk anti-bakteria dan bahan tambah dalam makanan. 


\section{Darfizzi et al: PRELIMINARY STUDY ON PRODUCTION OF MONOACYLGLYCEROL AND DIACYLGLYCEROL OF VIRGIN COCONUT OIL VIA ENZYMATIC GLYCEROLYSIS USING LIPASE Candida antarctica (Novozyme 435)}

Kata kunci: minyak kelapa dara, gliserolisis, enzim lipase, monoasilgliserol, diasilgliserol

\section{Introduction}

Monoacylglycerol and diacylglycerol are chemical compounds which having one or two acyl groups attached to the glycerol backbone. A mixture of monoacylglyceol (MAG) and diacylglycerol (DAG) are commercially manufactured via glycerolysis reaction, in which fats and oils reacted with gycerol and undergo a transesterification reaction. MAG and DAG have both hydrophilic and hydrophobic portions which make them known as nonionic molecules. The molecular structure of MAG contains two free hydroxyl groups while DAG has one [1]. These molecules show excellent emulsifying properties due to their characteristics, and thus, being widely applied in the food, cosmetics, pharmaceuticals and chemical industries. Figure 1 shows the chemical structure of MAG and DAG.

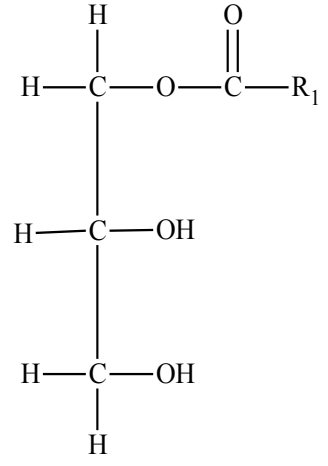

MAG

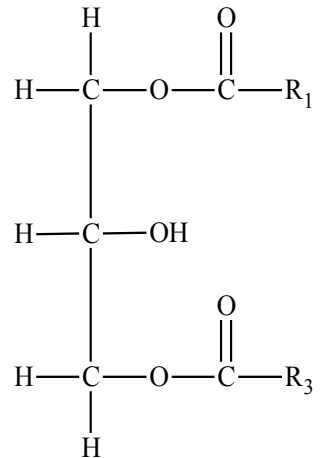

DAG

Figure 1. General chemical structure of MAG and DAG

Commercially, MAGs are used as binders in tablets and as emollients for transdermal slow-release drugs in the pharmaceutical industry. Furthermore, they are used as the most common food emulsifiers i.e. bakery products, margarines, dairy products, confectionery and sauces in the food industry. In cosmetics, they are often used as texturizing agents and for improving the consistency of creams and lotions [2]. In addition, MAGs are used in plastic production, textile processing and oil formulation for different types of machinery due to their excellent lubricating and plasticizing properties [3].

Meanwhile, DAGs are used as additives or carriers in the food, medicinal and cosmetic industry. A published literature proposed mechanisms for dietary DAG as it exhibits anti-obesity activity and can prevent postprandial hypertriacylglycerolemia in experimental animals and humans [4]. DAG oil has plentiful applications in edible products such as cooking oil, frying oil, salad oil and dressing, mayonnaise, shortening, margarine, chocolate and ice cream [5].

A previous work has attempted to manufacture MAGs and DAGs on an industrial scale by continuous chemical glycerolysis of fats and oils at high temperature $\left(220-250{ }^{\circ} \mathrm{C}\right)$ employing inorganic alkaline catalysts under nitrogen gas atmosphere [6]. Unfortunately, the products suffered a few discrepancies with several disadvantages in the process itself [7]. The products were unattractively dark-coloured and have a burnt taste due to the high reaction temperature involved. Nonetheless, the chemical catalysis process was energy intensive, thus low yields were produced $(30-40 \%)$ which acquired product purification by molecular distillation [8]. 
The use of enzymes as catalyst to modify the structure and composition of oils and fats has recently gained considerable attention, resulting in important advances in this specific field of biotransformation. Recently, enzymatic reactions have been considered as an alternative for chemical methods in large-scale productions [9]. Lipases are enzymes that hydrolyze fatty acids from lipid species such as triacylglycerols. Lipases catalyze the whole range of ester exchange reactions (alcoholysis, acidolysis, esterification, glycerolysis) and hydrolysis. The mild reaction condition and high purity MAG are the desirable advantages of enzymatic processes compared to chemical methods [10]. In parallel to green chemistry concept, enzyme reactions require less solvent which generated cleaner products. Figure 2 shows the X-ray structure of Candida antarctica lipase A. The enzyme is classified as hydrolase [11].

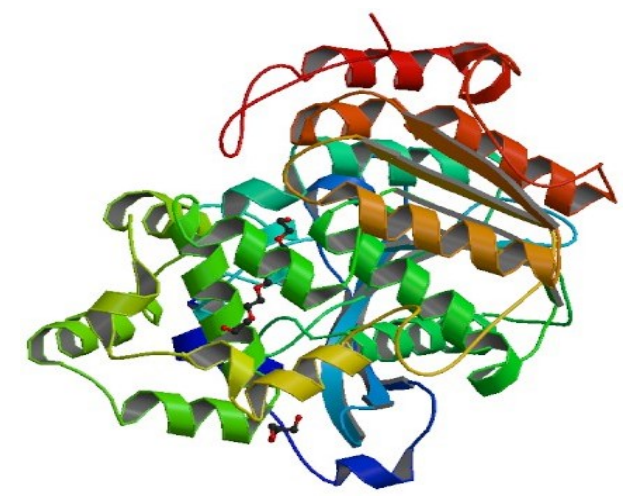

Figure 2. X-ray structure of Candida antarctica lipase A

Virgin coconut oil (VCO) is obtained from the fresh and mature kernel of the coconut (Cocos nucifera $\mathrm{L}$.) through mechanical and natural means. The selection methods could involve heat provided that it does not lead to alteration or transformation of the oil. Approximately $60 \%$ of the total oil of coconut oil being medium chain triglycerides (MCTs) and thus it is considered as a natural source of MCTs. The term MCT refers to triacylglycerol which is composed of a glycerol backbone and three saturated fatty acids with chain length of $6-12$ carbons. MCTs have been reported to be beneficial to human health. MCTs are mainly used as a nutritional supplement for patients suffering from absorbtion disability caused by intestinal resection and also as a component of infant feeding formulas [12]. A study had reported that MCTs have beneficial effects on weight control and glucose, as well as lipid metabolism [13]. Compared with other triglycerides that mainly contain saturated long chain fatty acids, MCTs have a lower melting point, smaller molecular size, lower solidification temperature and lower energy density. These distinct chemical properties affect the ways in which MCTs are absorbed and metabolized [14].

This preliminary study on enzymatic glycerolysis of VCO using a commercial immobilized Candida antarctica lipase (Novozyme 435) was performed to evaluate potential chemical modification method to produce MAGs and DAGs for various applications.

\section{Materials}

\section{Materials and Methods}

Virgin coconut oil (produced by Country Farm Sdn. Bhd.) was directly purchased from a local market and used without any pre-treatments. Lipase Candida antarctica (Novozyme 435) were purchased from Sigma-Aldrich and glycerol $(99.5 \%)$ were obtained from Systerm.

\section{Physicochemicals analysis of VCO Saponification value (SV)}

Saponification values (SV) were determined using the International Union of Pure and Applied Chemistry (IUPAC) method II.D.2 [15]. In a reflux condenser, $2.0 \mathrm{~g}$ of oil samples were added with Ethanolic $\mathrm{KOH} 0.5 \mathrm{~N}$ and boiled for 


\section{Darfizzi et al: PRELIMINARY STUDY ON PRODUCTION OF MONOACYLGLYCEROL AND DIACYLGLYCEROL OF VIRGIN COCONUT OIL VIA ENZYMATIC GLYCEROLYSIS USING LIPASE Candida antarctica (Novozyme 435)}

60 minutes. The mixtures were cooled and subsequently titrated with $0.5 \mathrm{~N} \mathrm{HCl}$ until the pink colour disappear and changed to colourless. All SV determinations were carried out in triplicates.

\section{Iodine value (IV)}

The determination of iodine value (IV) of oil was carried out according to the IUPAC method II.D.7 [15]. A reaction was held in the dark between $0.5 \mathrm{~g}$ of oil samples with the Wij's solution for 1 hour. The mixture was consequently titrated with sodium thiosulphate solution. IV values were determined in triplicates and expressed as gram of iodine absorbed by $100 \mathrm{~g}$ of the fats $\left(\mathrm{g} \mathrm{I}_{2} / 100 \mathrm{~g}\right)$.

\section{Free fatty acids value (FFA)}

Free fatty acid (FFA) value was ascertained using the IUPAC method II.D.1 [15]. An amount $5.0 \mathrm{~g}$ of oil samples were added with $50 \mathrm{~mL}$ of neutralized diethyl ether: ethanol $(1: 1 ; \mathrm{v} / \mathrm{v})$ and $1-2 \mathrm{~mL}$ of phenolphthalein indicator. The mixture was heated on a hot plate with controlled temperature around $40{ }^{\circ} \mathrm{C}$. It was then titrated with a standard $\mathrm{NaOH}$ until a constant pink colour was obtained. All FFA value determinations were conducted in triplicates and expressed as $\mathrm{mg}$ of $\mathrm{KOH}$ required to neutralize the free fatty acids in $1 \mathrm{~g}$ of $\mathrm{VCO}$ ( $\mathrm{mg} \mathrm{KOH} / \mathrm{g}$ oil).

\section{Peroxide value (PV)}

The determination of Peroxide Value (PV) was carried out according to AOCS Cd 8b-90 [16]. An amount $5.0 \mathrm{~g}$ of samples were added with $30 \mathrm{~mL}$ of mixture of acetic acid and chloroform in a conical flask and mixed well. Then, $0.5 \mathrm{~mL}$ of concentrated potassium iodide $(\mathrm{KI})$ was pipetted into the mixture and the flask was manually shaken for a minute. After shaking, $30 \mathrm{~mL}$ of distilled water and few drops of starch were added and the mixture was titrated gradually with $0.01 \mathrm{~N}$ sodium thiosulphate until the blue colour has disappeared.

\section{Moisture content}

Determination of moisture content was based on the AOAC method [17] with slight alteration. Sample was weighed and heated at $105{ }^{\circ} \mathrm{C}$ in a crucible for at least 7 hours and then, cooled to room temperature. The crucible was reweighed with the sample inside until constant readings were gathered. Moisture content was calculated based on weight difference obtained.

\section{Fatty acids methyl ester (FAME) analysis}

Exactly $0.2 \mathrm{ml}$ oil samples were prepared by dissolving in hexane and later added with $0.2 \mathrm{~mL}$ of $1 \mathrm{M}$ sodium methoxide. The mixture was vortexed and FAME solution in the upper layer was collected for GC-FID analysis. The analysis of FAME was conducted with Shimadzu GC-17A gas chromatography equipped with a flame ionization detector (FID). BPX-70 column was used in this experiment $(0.25 \mathrm{~mm}$ internal diameter, $30 \mathrm{~m}$ length and $0.25 \mu \mathrm{m}$ film thickness). The column was initially set at $100{ }^{\circ} \mathrm{C}$ and held for 3 minutes, then increased to $245^{\circ} \mathrm{C}$ and held for another $10 \mathrm{~min}$ at a rate of $4{ }^{\circ} \mathrm{C} / \mathrm{min}$. The temperature of injector and detector port were $250{ }^{\circ} \mathrm{C}$ and $280{ }^{\circ} \mathrm{C}$ respectively. Helium gas with purity level $99.99 \%$ is used as carrier gas.

\section{Enzymatic glycerolysis reaction}

Glycerolysis reaction was modified based on a research conducted by Pinyahpong et al. [18]. The molar ratio used for VCO:glycerol was 1:1. An approximately $2.8 \%(\mathrm{w} / \mathrm{v})$ of distilled water was added based on the volume of oil used and $3 \% \mathrm{wt}$ of lipase enzyme was added based on the weight of glycerol. The reaction was carried out at $50{ }^{\circ} \mathrm{C}$ in a shaking incubator with $250 \mathrm{rpm}$ for 24 hours.

After 24 hours, the reaction stopped and the enzyme was then separated from the mixture using filter paper in a present of vacuum condition. The filtrate was placed into a separating funnel and followed by $50 \mathrm{~mL}$ of chloroform, $50 \mathrm{~mL}$ of ethanol and $30 \mathrm{~mL}$ of diethyl ether were added to separate excess glycerol. The mixture was then washed with $100 \mathrm{~mL}$ of sodium chloride (4 times) and $100 \mathrm{ml}$ of sodium hydroxide (4 times). This is to remove the free fatty acids from the glycerolysis reaction. Finally, the product was obtained after using rotary evaporator. This paper will discuss some factors that affected lipase-catalysed glycerolysis such as time of reaction ( 24 hours and 48 hours) and enzyme concentration used; $3 \%, 5 \%$ and $10 \%$ of glycerol $(\mathrm{w} / \mathrm{w})$. 


\section{Chemical compositions analysis}

Product identification was analysed using Thin Layer Chromatography (TLC). An aliquots of the reaction mixtures were applied on a silica gel 60 plate (Merck) in developing solvent mixture of $n$-hexane:diethyl ether:acetic acid $(70: 30: 1 ; \mathrm{v} / \mathrm{v})$. The spots of each product were visualized by immersing the plate in $\mathrm{KmNO}_{4}$ solution.

The composition of products were analysed by using gas chromatography (Shimadzu GC-17A) fitted with a capillary column (DB-5ht, $30 \mathrm{~m} \times 0.320 \mathrm{~mm}, 0.25 \mu \mathrm{m}$ thickness) and equipped with a flame ionization detector (FID). The separation of compounds was performed using the following oven temperature profile: initial temperature $80{ }^{\circ} \mathrm{C}$, programmed to $350{ }^{\circ} \mathrm{C}$ at $10{ }^{\circ} \mathrm{C} / \mathrm{min}$, and final temperature held for $10 \mathrm{~min}$. The sample was prepared by adding $0.03 \mathrm{~mL}$ of sample in $1 \mathrm{~mL}$ of ethyl acetate in a vial. Only $0.1 \mu \mathrm{L}$ of the prepared sample was injected into GC.

The functional groups analysis of product was determined using FT-IR spectroscopy. In this study, FT-IR with the model of Perkin Elmer Spectrum BX was used. The sample was smeared thinly on the NaCl plate and FT-IR spectrum was recorded.

\section{Physicochemicals properties of VCO}

\section{Results and Discussion}

The results obtained were within accepted levels according to Asian Pacific Coconut Community (APCC) specifications [19] as shown in Table 1. The molecular mass determined for VCO is $651.57 \mathrm{~g} / \mathrm{mol}$. VCO was converted to fatty acids methyl ester (FAME) and its composition was determined by using gas chromatography. A standards of FAME was calibrated and established for each peak of compound prior sample analysis. The chromatogram of methyl esters of VCO is shown in Figure 3.

Table 1. Physicochemical Properties of VCO

\begin{tabular}{lcc}
\hline Tests & Value & APCC Standard \\
\hline Saponification Value $(\mathrm{mg} \mathrm{KOH} \mathrm{/} \mathrm{g)}$ & 258.30 & $250-260$ \\
Free Faty Acids $(\mathrm{mg} \mathrm{KOH} \mathrm{/} \mathrm{g)}$ & 0.225 & $0.5 \mathrm{max}$ \\
Iodine Value $\left(\mathrm{g} \mathrm{I}_{2} / 100 \mathrm{~g}\right)$ & 4.13 & $4.1-11.0$ \\
Peroxide Value $(\mathrm{meq} / \mathrm{kg})$ & 0.2 & $3.0 \mathrm{mas}$ \\
Moisture Content $(\%$ weight $)$ & 0.11 & $0.1-0.5$ \\
\hline
\end{tabular}

Retention time is the time taken by certain compounds to move along the column towards the detector. This period depends on the boiling point of each compound. Compounds with higher boiling points have longer retention period. In general, the boiling point of the compound was influenced by several molecular factors such as the number of carbon (carbon chain length) and the number of double bonds that exist in the compound. The number of carbon is in conjunction with the molecular weight of these compounds. Heavier molecules (high molecular weight) have higher boiling points. This caused the molecule to be less volatile and therefore will be detected slower, thus prolonged its detention time. Similarly, compounds with more double bonds have longer period of detention [20].

The peaks composition of product were compared with the retention times of calibrated methyl esters standards as followed, mehyl caprilate $(3.375 \mathrm{~min})$; methyl caprate $(5.581 \mathrm{~min})$; methyl laurate $(9.071 \mathrm{~min})$; methyl myristate (12.913 min); methyl palmitate (16.708 min); methyl stearate (20.283 min); methyl oleate (20.853 min) and methyl linolate $(22.022 \mathrm{~min})$. From the observation on the GC result, methyl caprylate that has 6 carbons had the shortest retention time and was detected the earliest. Methyl stearate has 18 carbons which produced longer detention period. Meanwhile, methyl stearate, oleate and linolate have the same carbon number of 18. However, linolate has 2 double bonds and thus, produced the longest detention period. 


\section{Darfizzi et al: PRELIMINARY STUDY ON PRODUCTION OF MONOACYLGLYCEROL AND DIACYLGLYCEROL OF VIRGIN COCONUT OIL VIA ENZYMATIC GLYCEROLYSIS USING LIPASE Candida antarctica (Novozyme 435)}

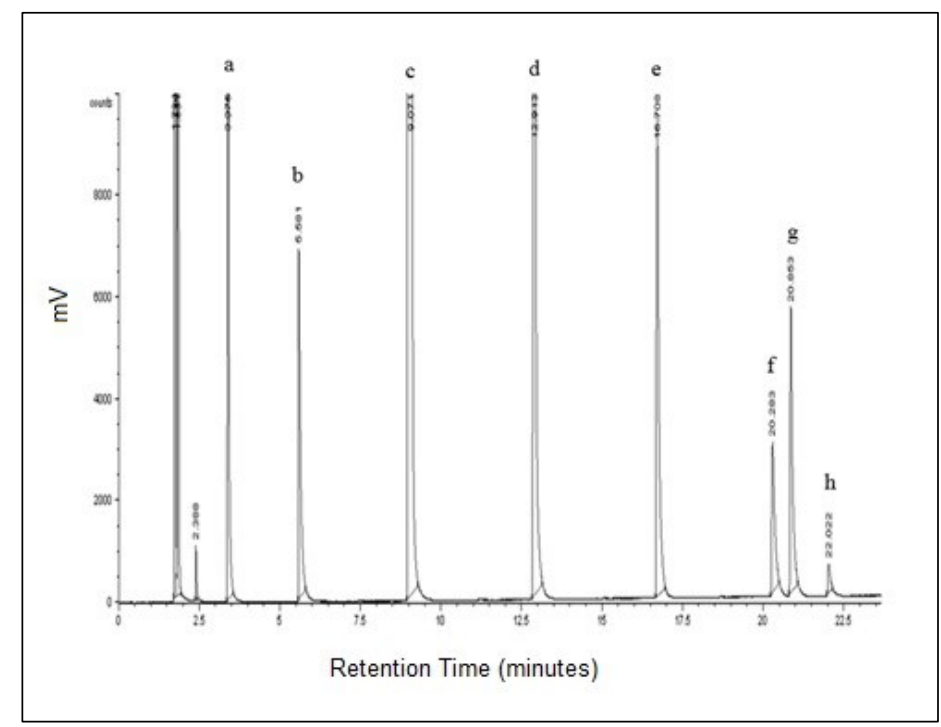

Figure 3. GC chromatogram of VCO (a: methyl caprilate, b: methyl caprate, c: methyl laurate, d: methyl myristate, e: methyl palmitate, f: methyl stearate, g: methyl oleate, h: methyl linolate)

The carbon chain composition of VCO was tabulated in Table 2 and compared to APCC standard [19]. The results showed that VCO sample consists of caprylic (C8:0), capric (C10:0), lauric (C12:0), myristic (C14:0), palmitic (C16:0), stearic (C18:0), oleic (C18:1) and linoleic (C18:2). It was found that VCO contains high saturated fatty acids (SFA) which was $93.9 \%$ and low unsaturated fatty acids which was $6.0 \%$. These findings were in agreement with Mansor et al [12].

Table 2. Fatty acids composition of VCO

\begin{tabular}{lcc}
\hline Fatty Acid Composition & Percentage (\%) & APCC Standard (\%) \\
\hline Caprylic acid & 6.3 & $4.6-10.0$ \\
Capric acid & 5.4 & $5.0-8.0$ \\
Lauric acid & 48.8 & $45.1-53.2$ \\
Myristic acid & 20.0 & $16.8-21.0$ \\
Palmitic acid & 9.8 & $7.5-10.2$ \\
Stearic acid & 3.6 & $2.0-4.0$ \\
Oleic acid & 5.4 & $5.0-10.0$ \\
Linoleic acid & 0.6 & $1.0-2.5$ \\
\hline
\end{tabular}

\section{Product compositions}

TLC was used to validate the products after the reaction. Based on the results, TLC plate confirmed the product formation. MAG (i) was detected first, followed by 1,2-DAG (ii), 1,3-DAG (iii) and TAG (iv) respectively (Figure 4). The components were detected based on their polarity. No fatty acids were detected on the TLC plate. 

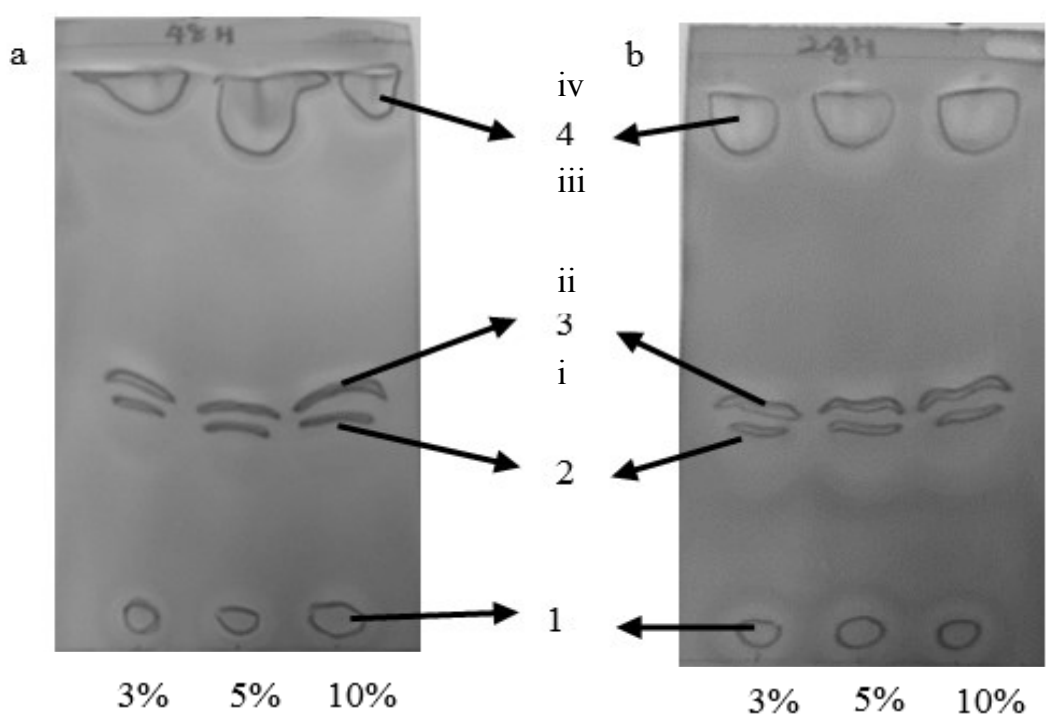

Figure 4. TLC plate of glycerolysis reaction (a: Reaction time for 48 hours; b: Reaction time for 24 hours)

In this study, glycerolysis between VCO and glycerol (molar ratio 1:1) with 3, 5 and $10 \%$ wt of ezyme concentration at $50{ }^{\circ} \mathrm{C}$ for 24 and 48 hours were investigated. The results showed that $3 \%$ wt of enzyme at 24 hours of reaction gave $1.4 \% \mathrm{MAG}, 2.2 \%$ DAG and $96.4 \%$ of unreacted TAG. It was observed that $5 \%$ of enzyme at 24 hours of reaction yielded increment on MAG and DAG contents. However, there were no increment observed for conversion of MAG and DAG if increase the enzyme concentration to $10 \% \mathrm{wt}$. The reaction was continued with pro-long the reaction time. It was reported that no significant increment of MAG and DAG content for 48 hours at any enzyme concentrations. The percentage of conversions are still low and not fully optimized. But, this findings proved that the conversion of VCO in TAG form into simpler compounds (MAG and DAG) is possible to be done through enzymatic glicerolysis with further investigations. Some parameters have to optimized and different types of lipase enzymes have to be considered for this reaction. In order to push forward the reaction, selected factors that may favour the reaction have been studied such as time of reaction (RT) and percentage of enzyme concentrations. Based on the results (Table 3), glycerolysis with $5 \%$ of enzyme loading and 24 hours of reaction time gave the highest composition of MAG and DAG.

Table 3. Compositions of products

\begin{tabular}{ccccc}
\hline Enzyme Concentration & Reaction Time & \multicolumn{3}{c}{ Product Compositions (\%) } \\
\cline { 3 - 5 }$(\mathbf{\%})$ & (hours) & MAG & DAG & TAG \\
\hline 3 & 24 & 1.4 & 2.2 & 96.4 \\
5 & 24 & 3.3 & 3.6 & 93.1 \\
10 & 24 & 1.5 & 3.2 & 95.3 \\
3 & 48 & 0.5 & 1.5 & 98.0 \\
5 & 48 & 0.6 & 1.2 & 98.2 \\
10 & 48 & 1.6 & 2.4 & 96.0 \\
\hline
\end{tabular}




\section{Darfizzi et al: PRELIMINARY STUDY ON PRODUCTION OF MONOACYLGLYCEROL AND DIACYLGLYCEROL OF VIRGIN COCONUT OIL VIA ENZYMATIC GLYCEROLYSIS USING LIPASE Candida antarctica (Novozyme 435)}

\section{Conclusion}

Preliminary findings conclude that glycerolysis reaction of VCO as the starting material was successfully performed. The optimum condition for the reaction was $5 \%$ enzyme loading at $50{ }^{\circ} \mathrm{C}$ for 24 hours of reaction time. Based on GC analysis results, the product comprises 3.3\% MAG, 3.6\% DAG and 93.1\% TAG. The product identification was further confirmed through TLC plate analysis technique.

\section{Acknowledgement}

Authors would like to acknowledge Universiti Kebangsaan Malaysia and Ministry of Higher Education for the research facilities and financial support provided through research grant no. FRGS/2/2014/ST01/UKM/02/2.

\section{References}

1. Chen, B., McClements, D. J. and Decker, E. A. (2014). Impact of diacylglycerol and monoacylglycerol on the physical andchemical properties of stripped soybean oil. Food Chemistry, 142: 365 - 372.

2. Al-Darmaki, N., Lu, T., Al-Duri, B., Harris, J. B., Favre, T. L. F., Bhaggan, K. and Santos, R. C. D. (2011). Solubility measurements and analysis of binary, ternary and quaternary systems of palm olein, squalene and oleic acid in supercritical carbon dioxide. Separation and Purification Technology, 83: 189- 195.

3. Pyo, Y. G., Hong, S. I., Kim, Y., Kim, B. H. and Kim, I. H. (2012). Synthesis of monoacylglycerol containing pinolenic acid via stepwise esterification using a cold active lipase. Biotechnology Progress, 28(5): $1218-$ 1224.

4. Kielczynski, P., Szalewski, M., Balcerzak, A., Malanowski, A., Siegoczynski, R. M. and Ptasznik, S. (2012). Investigation of high-pressure phase transitions in DAG (diacylglycerol) oil using the Bleustein-Gulyaev ultrasonic wave method. Food Research International, 49: 60 - 64.

5. Reyes, G., Yasunaga, K., Rothenstein, E., Karmally, W., Ramakrishnan, R. and Holleran, S. (2008). Effects of a 1,3-diacylglycerol oil-enriched diet on postprandial lipemia in people with insulin resistance. Journal of Lipid Research, 49: $670-678$.

6. Sonntag (1982). Glycerolysis of fats and methyl esters - status. Journal of the American Oil Chemists' Society, 59(10): $795-802$.

7. Bornscheuer, U. T. (1995). Lipase-catalyzed Syntheses of Monoacylglycerols. Enzyme and Microbial Technology, 17: $578-586$.

8. Ferreira-Dias, S., Correia, A. C., Baptista, F. O. and Fonseca, M. M. R. (2001). Contribution of response surface design to the development of glycerolysis systems catalyzed by commercial immobilized lipases. Journal of Molecular Catalysis B: Enzymatic, 11: $699-711$.

9. Zhu, Q., Li, T., Wang, Y., Yang, B. and Ma, Y. (2011). A two-stage enzymatic process for synthesis of extremely pure high oleic glycerol monooleate. Enzyme and Microbial Technology, 48: 143 - 147.

10. Gunstone, F. D. (1999). Enzymes as biocatalysts in the modification of natural lipids. Journal of the Science of Food and Agriculture, 79(12): 1535 - 1549.

11. Brandt, A. M., Li, X. G., Nymalm-Rejstrom, Y., Airenne, T., Kanerva, L. T. and Salminen, T. A (2009). The X-ray Structure of Candida antarctica Lipase A. RCSB Protein Data Bank (PDB).

12. Mansor, T. S. T., Che, Man, Y. B., Shuhaimi, M., Abdul, Afiq, M. J. and Ku, Nurul, F. K. M. (2012). Physicochemical properties of virgin coconut oil extracted from different processing methods. International Food Research, 19(3): 837 - 845.

13. Marten, B., Pfeuffer, M. and Schrezenmeir, J. (2006). Medium-chain triglyceride (review). International Dairy Journal, 16: $1374-1382$.

14. International Union of Pure and Applied Chemistry (IUPAC) (1979). Standard Methods for the Analysis of Oils, Fats and Derivatives. $6^{\text {th }}$ edition. Oxford: Pergamon Press.

15. Nandi, S., Gangopadhyay, S. and Ghosh, S. (2005). Production of medium chain glycerides from coconut and palm kernel fatty acid distillates by lipasecatalyzed reaction. Enzyme and Microbial Technology, 36: 725 - 728.

16. PORIM (1995) PORIM test method. Malaysia: Palm Oil Research Institute of Malaysia.

17. AOAC Official Methods Of Analysis (1997). Association of Official Analytical Chemists. 17th edition. Washington DC.

18. Pinyahpong, P, Sriburi, P and Phutrakul, S. (2012). Synthesis of monoacylglycerol from glycerolysis of crude glycerol with coconut oil catalyzed by Carica papaya lipase. International Journal of Chemical, Molecular, Nuclear, Materials and Metallurgical Engineering, 6 (10): 926 - 931. 
19. Asian and Pacific Coconut Community (2003). Internet: standard for virgin coconut oil. Downloaded from http://www.apccsec.org/standards.htm/ [Date access 15/1/2015].

20. Littlewood, A. B. (1970). Gas chromatography: Principles, techniques and applications. New York: Academic Press. 